\title{
Growth and Seed Yield of Annual Chrysanthemum as Influenced by Different Levels of Nitrogen and Potassium
}

\author{
B.S. Nikam ${ }^{1}$, S.A. Badge ${ }^{2 *}$ and A.R. Pawar ${ }^{1}$ \\ ${ }^{1}$ Horticulture Section, College of Agriculture, Nagpur 440001 (M.S.), India \\ ${ }^{2}$ Horticulture, Agriculture Research Station, Sonapur-Gadchiroli-442605 (MS), India \\ *Corresponding author
}

\section{A B S T R A C T}

Keywords

Nitrogen,

Potassium, Growth,

Flowering, Annual

chrysanthemum

Article Info

Accepted:

06 August 2018

Available Online:

10 September 2018
An experiment was carried out at Horticulture Section, College of Agriculture, Nagpur during rabi season of the year 2017-18 to study the effect of nitrogen and potassium on growth and flowering of annual chrysanthemum. The treatment comprised of four levels of nitrogen $\left(0,100,150\right.$ and $\left.200 \mathrm{~kg} \mathrm{~N} \mathrm{ha}^{-1}\right)$ and four levels of potassium $(0,50,75$ and $100 \mathrm{~kg}$ $\mathrm{ha}^{-1}$ ) in all sixteen treatments combinations planted in factorial randomized block design with three replications. The results revealed that plant height $(112.95 \mathrm{~cm}$ and $110.54 \mathrm{~cm}$ respectively), stem diameter $(2.65 \mathrm{~cm}$ and $2.55 \mathrm{~cm}$ respectively), number of branches (29.36 and 28.05 respectively), spread of plant $(63.13 \mathrm{~cm}$ and $59.44 \mathrm{~cm}$ respectively) and leaf area $\left(28.10 \mathrm{~cm}^{2}\right.$ and $25.49 \mathrm{~cm}^{2}$ respectively) were recorded significantly maximum with the treatment individual application of $200 \mathrm{~kg}$ nitrogen and $75 \mathrm{~kg} \mathrm{~K} \mathrm{ha}{ }^{-1}$. Yield contributing characters like number of flower plant ${ }^{-1}$ (113.26 and 107.43), number of seed flower $^{-1}$ (211.41), seed yield flower ${ }^{-1}$ (30.55 g), plot $^{-1}$ (624.97 g) and ha ${ }^{-1}$ (11.00 qt) were recorded significantly maximum with the treatment individual application of $200 \mathrm{~kg}$ nitrogen and $75 \mathrm{~kg} \mathrm{~K} \mathrm{ha}^{-1}$.

\section{Introduction}

Annual chrysanthemum (Chrysanthemum coronarium) is one of the most important flower crops grown in India, though it is originated in South Europe. It is a winter annual crop and belongs to the family Asteraceae. It is also known as 'Crown Daisy' or 'Garland chrysanthemum'. Because of variation in size, shape and colour of flowers, the annual chrysanthemum is popular among the people. Annual or garland chrysanthemum is one of the commercially important cultivated flower crops grown for its loose flowers in several parts of India. It produces white and yellow coloured blooms and generally used in garland making, veni, floral decoration, religious function as well as bedding material in the landscape gardens. The crop has relatively short duration and further considered photo-insensitive. Under moderate climatic conditions flowering is observed almost throughout the year. The plant is considered to be hardier, vigorous and grows taller.These flowers have constant demand during the days of festivals, functions, in the place of worshiping and decoration throughout the year. 
Andhra Pradesh is considered the most prominent chrysanthemum growing state followed by Karnataka, Maharashtra, Telangana and Chhattisgarh. However, in Maharashtra the annual chrysanthemum crop is coming up very well, hence there is a need to develop package of practices to increase the flower yield coupled with quality. Application of major nutrients viz., nitrogen, phosphorous and potassium play an important role in growth and development of many flower crops thereby increase the flower yield. Based on the available literature, it is evident that very little research work was carried out earlier on vegetative growth, floral and seed yield responses of garland chrysanthemum to different levels of nitrogen and potassium in many parts of the country especially in the Vidarbha region. Keeping all these things in view, the present investigation has been planned to study the requirement of optimum level of nitrogen and potassium for good constructive vegetative growth and seed yield of annual chrysanthemum with the aim to find out the effect of different levels of nitrogen, potassium and their interactions on vegetative growth and seed yield of annual chrysanthemum.

\section{Materials and Methods}

The present investigation was carried out during rabi season of the year 2017-18 at Horticulture Section, College of Agriculture, Nagpur. The experimental site had medium to Sandy loam in texture. The soil had moderately and well drained. There were 16 treatment combinations consisting of 4 doses each of nitrogen viz., $\mathrm{N}_{1}\left(100 \mathrm{~kg} \mathrm{ha}^{-1}\right), \mathrm{N}_{2}(150$ $\left.\mathrm{kg} \mathrm{ha}^{-1}\right), \mathrm{N}_{3}\left(200 \mathrm{~kg} \mathrm{ha}^{-1}\right)$ and $\mathrm{N}_{4}$ - control (0 $\left.\mathrm{kg} \mathrm{ha}^{-1}\right)$ and Potassium viz., $\mathrm{K}_{1}\left(50 \mathrm{~kg} \mathrm{ha}^{-1}\right), \mathrm{K}_{2}$ $\left(75 \mathrm{~kg} \mathrm{ha}^{-1}\right), \mathrm{K}_{3}\left(100 \mathrm{~kg} \mathrm{ha}^{-1}\right)$ and $\mathrm{K}_{4}$-control $0 \mathrm{~kg} \mathrm{ha}^{-1}$ ) with a constant dose of phosphorus $\left(100 \mathrm{~kg} \mathrm{ha}^{-1}\right)$ application in the soil. The experiment was laid out in factorial randomized block design with three replications. The experimental gross plot size was $2.25 \mathrm{~m} \times 1.80 \mathrm{~m}$. The spacing adopted was $45 \mathrm{~cm} \times 30 \mathrm{~cm}$. The straight fertilizers viz., Urea, Single Super Phosphate and Muriate of Potash were taken as the sources of nitrogen, phosphorus and potassium, respectively. Entire dose of phosphorus was applied in the soil as a basal dose. As regards the treatments, half dose of nitrogen along with full dose of potassium was applied at the time of planting as per treatments. Remaining half dose of nitrogen was applied at 30 after planting as per the treatments fixed. Growth parameters viz., plant height, number of branches plant ${ }^{-1}$, stem diameter, plant spread, leaf area, yield parameters viz., number of flower, number of seed flower ${ }^{-1}$, seed yield flower ${ }^{-1}$, $\operatorname{plot}^{-1}$ and hectare ${ }^{-1}$ were recorded. The data recorded on each character were analyzed by the ANOVA technique as described by Panse and Sukhatme (1967). The treatment means were compared using the critical difference values calculated at 5 per cent level of significance.

\section{Results and Discussion}

Data from table 1 observed the significant differences in the vegetative growth due to the application of nitrogen and potassium in different doses. However, the interaction effects were found to be non-significant in annual chrysanthemum the rabi season.

\section{Effect of nitrogen on vegetative growth and seed yield}

Data from table 1 revealed that significantly highest plant height $(112.95 \mathrm{~cm})$, stem diameter $(2.65 \mathrm{~cm})$, number of branches plant $^{-1}$ (29.36), spread of plant $(63.13 \mathrm{~cm})$ and leaf area $\left(28.10 \mathrm{~cm}^{2}\right)$ was recorded with the application of nitrogen at the rate of $200 \mathrm{~kg}$ $\mathrm{ha}^{-1}(88.85 \mathrm{~cm})$ when compared with all other doses of nitrogen followed by $150 \mathrm{~kg}$ of nitrogen $\mathrm{ha}^{-1}$. Significantly minimum values in 
respect of plant height, $(100.50 \mathrm{~cm})$, stem diameter $(2.11 \mathrm{~cm})$, number of branches plant $^{-1}(21.13)$, spread of plant $(45.76 \mathrm{~cm})$ and leaf area $\left(17.89 \mathrm{~cm}^{2}\right)$ were recorded in control i.e. no application of nitrogen. Based on the result obtained it may be concluded that, significant differences were observed in the vegetative growth characters with the application of different levels of nitrogen individually. Vegetative growth characters were found to be increased dose of nitrogen upto $200 \mathrm{~kg} \mathrm{ha}^{-1}$. It is considered that nitrogen acts as an essential part in the biosynthesis of nucleic acids hence, plays a vital role in promoting the plant growth. Further, nitrogen has been identified as an important constituent of chlorophyll, proteins and amino acids thereby enhancing the rate of photosynthesis. The increase in vegetative growth so thought might be due to greater uptake of nutrients into the plant system through soil application which finally involved in the cell division, cell elongation as well as protein synthesis which ultimately enhanced the stem length and vegetative growth. Similar kind of observations with an increase in vegetative growth by the external application of higher dose of fertilizers was noticed by Karavadia and Dhaduk (2002) in annual chrysanthemum, Shinde et al., (2014) in African marigold, Singh and Nigam (2015) in chrysanthemum, Kumar et al.,(2016) in China aster and Satar et al., (2016).

The data pertaining to seed yield of annual chrysanthemum was presented in table 1 . Among the nitrogen treatments, application of nitrogen at the rate of $200 \mathrm{~kg} \mathrm{ha}^{-1}$ had recorded significantly maximum number of flower plant ${ }^{-1}$ (113.26), number of seed plant $^{-1}$ (221.45), seed yield plant $^{-1}$ (31.34 g), plot $^{-1}$ $(652.60 \mathrm{~g})$ and hectare ${ }^{-1}(11.68 \mathrm{q})$ when compared with all other doses of nitrogen application followed by $150 \mathrm{~kg}$ nitrogen hectare $\mathrm{ha}^{-1}$. Significantly, minimum number of flower plant $^{-1}$ (83.68), number of seed plant $^{-1}$ (187.57), seed yield plant ${ }^{-1}(187.57 \mathrm{~g})$, plot $^{-1}(510.87 \mathrm{~g})$ and hectare ${ }^{-1}(8.34 \mathrm{q})$ in control treatment. Based on the results obtained, it may be concluded that flower and seed yield increased with the application of nitrogen levels. The yield of flowers per plant increased with the application of nitrogen mainly because of increased carbohydrate reserve for the development of floral primordia apart from the structural development of the plant. The present results were in confirmation with the earlier findings of Chavan et al., (2010) in China aster, Solanki and Ganie (2010), Shinde et al., (2014) in African marigold and Tembhare et $a l .$, (2016) in China aster,

\section{Effect of potassium on vegetative growth and seed yield}

Data from table 1 revealed that, significantly maximum plant height, $(110.54 \mathrm{~cm})$, stem diameter $(2.55 \mathrm{~cm})$, number of branches plant $^{-1}(28.05)$, spread of plant $(59.44 \mathrm{~cm})$ and leaf area $\left(25.49 \mathrm{~cm}^{2}\right)$ was recorded with the application of potassium $75 \mathrm{~kg} \mathrm{ha}^{-1}$ when compared with all other doses of potassium which was at par with $100 \mathrm{~kg}$ of potassium $\mathrm{ha}^{-1}$. Significantly minimum values in respect of plant height, $(103.04 \mathrm{~cm})$, stem diameter $(2.23 \mathrm{~cm})$, number of branches plant ${ }^{-1}(23.64)$, spread of plant $(50.23 \mathrm{~cm})$ and leaf area $(20.03$ $\mathrm{cm}^{2}$ ) were recorded in control i.e. no application of potassium treatment. Potassium plays a vital role in the cell division and cellular differentiation in the plant system. Collins and Duke (1981) opined that potassium increased the rate of carbon exchange in the plant system thereby enhanced the movement of photosynthates in the phloem tissue which led to an increase in the meristematic activity of the plant system. This is due to potassium increases protein synthesis which might have been responsible for the significant increase in vegetative growth with the increase level of potassium. 
Table.1 Effect of nitrogen and potassium on growth and seed yield of annual chrysanthemum

\begin{tabular}{|c|c|c|c|c|c|c|c|c|c|c|}
\hline Treatments & $\begin{array}{c}\text { Plant } \\
\text { height } \\
(\mathrm{cm})\end{array}$ & $\begin{array}{c}\text { Stem } \\
\text { diameter } \\
(\mathrm{cm})\end{array}$ & $\begin{array}{l}\text { Number of } \\
\text { branches } \\
\text { plant }^{-1} \\
(\mathrm{~cm})\end{array}$ & $\begin{array}{c}\text { Spread } \\
\text { of } \\
\text { plant } \\
(\mathrm{cm})\end{array}$ & $\begin{array}{l}\text { Leaf } \\
\text { area } \\
\left(\mathrm{cm}^{2}\right)\end{array}$ & $\begin{array}{c}\text { Number } \\
\text { of } \\
\text { flowers } \\
\text { plant }^{-1}\end{array}$ & $\begin{array}{l}\text { Number } \\
\text { of seeds } \\
\text { flower }^{-1}\end{array}$ & $\begin{array}{c}\text { Seed } \\
\text { yield } \\
\text { plant }^{-1} \\
(\mathrm{~g})\end{array}$ & $\begin{array}{l}\text { Seed yield } \\
\text { plot }^{-1}(\mathrm{~g})\end{array}$ & $\begin{array}{l}\text { Seed yield } \\
\mathrm{ha}^{-1}(\mathbf{q})\end{array}$ \\
\hline \multicolumn{11}{|c|}{ Effect of Nitrogen (N) } \\
\hline $\mathrm{N}_{1-0} 0 \mathrm{~kg} \mathrm{Nha}$ & 100.50 & 2.11 & 21.13 & 45.76 & 17.89 & 83.68 & 187.57 & 25.29 & 510.87 & 8.34 \\
\hline $\mathrm{N}_{2}-100 \mathrm{~kg} \mathrm{~N} \mathrm{ha}^{-1}$ & 107.56 & 2.41 & 26.96 & 55.92 & 23.41 & 99.67 & 202.44 & 28.48 & 597.29 & 10.18 \\
\hline $\mathrm{N}_{3}-150 \mathrm{~kg} \mathrm{~N} \mathrm{ha}^{-1}$ & 109.85 & 2.55 & 27.59 & 59.37 & 25.49 & 107.97 & 205.59 & 29.23 & 623.45 & 10.62 \\
\hline $\mathrm{N}_{4}-200 \mathrm{~kg} \mathrm{~N} \mathrm{ha}^{-1}$ & 112.95 & 2.65 & 29.36 & 63.13 & 28.10 & 113.26 & 221.45 & 31.34 & 652.60 & 11.68 \\
\hline F test & Sig & Sig & Sig & Sig. & Sig & Sig. & Sig. & Sig & Sig & Sig. \\
\hline SE $\mathbf{m} \pm$ & 1.93 & 0.05 & 0.74 & 1.06 & 0.48 & 0.26 & 3.92 & 0.78 & 10.36 & 0.23 \\
\hline C.D. at 5\% & 5.59 & 0.13 & 2.14 & 3.08 & 1.38 & 6.23 & 11.32 & 2.27 & 29.94 & 0.66 \\
\hline \multicolumn{11}{|c|}{ Effect of Potassium (K) } \\
\hline $\mathrm{K}_{1}-0 \mathrm{~kg} \mathrm{~N} \mathrm{ha-1}$ & 103.04 & 2.23 & 23.64 & 50.23 & 20.03 & 92.24 & 195.10 & 26.50 & 547.06 & 9.12 \\
\hline $\mathrm{K}_{2^{-}} 50 \mathrm{~kg} \mathrm{~N} \mathrm{ha}^{-1}$ & 107.76 & 2.40 & 25.56 & 56.33 & 24.09 & 100.09 & 199.71 & 28.11 & 590.25 & 10.12 \\
\hline $\mathrm{K}_{3^{-}} 75 \mathrm{~kg} \mathrm{~N} \mathrm{ha}^{-1}$ & 110.54 & 2.55 & 28.05 & 59.44 & 25.49 & 107.43 & 211.41 & 30.55 & 624.97 & 11.00 \\
\hline $\mathrm{K}_{4}-100 \mathrm{~kg} \mathrm{~N} \mathrm{ha}{ }^{-1}$ & 109.49 & 2.53 & 27.77 & 58.18 & 25.27 & 104.82 & 210.82 & 29.18 & 621.93 & 10.58 \\
\hline F test & Sig & Sig & $\mathrm{Sig}$ & Sig & Sig & Sig & Sig. & Sig & Sig & Sig. \\
\hline SE $\mathbf{m} \pm$ & 1.93 & 0.05 & 0.74 & 1.06 & 0.48 & 0.26 & 3.92 & 0.78 & 10.36 & 0.23 \\
\hline C.D. $5 \%$ & 5.59 & 0.13 & 2.14 & 3.08 & 1.38 & 6.23 & 11.32 & 2.27 & 29.94 & 0.66 \\
\hline \multicolumn{11}{|c|}{ Interaction effect $\mathbf{N} \times \mathbf{K}$} \\
\hline F test & N.S. & N.S. & N.S. & N.S. & N.S. & N.S. & N.S. & N.S. & N.S. & N.S. \\
\hline SE $\mathbf{m} \pm$ & 4.74 & 0.11 & 1.81 & 2.61 & 1.17 & 5.28 & 9.60 & 1.97 & 25.29 & 0.56 \\
\hline C.D. & -- & -- & -- & -- & -- & -- & -- & -- & -- & -- \\
\hline
\end{tabular}


These results were in close conformity with the findings of Mittal et al., (2010) in African marigold and Karetha et al., (2011) in gaillardia. Palagani et al., (2015) in chrysanthemum and Kabariel et al., (2016) in African marigold.

As regards the seed yield, among the potassium treatments, an application of potassium at the rate of $75 \mathrm{~kg} \mathrm{ha}^{-1}$ had recorded significantly highest number of flower plant ${ }^{-1}$ (107.43), number of seed plant ${ }^{-1}$ (211.41), seed yield plant $^{-1}(30.55 \mathrm{~g})$, plot $^{-1}$ $(624.93 \mathrm{~g})$ and $\operatorname{hectare}^{-1}(11.00 \mathrm{q})$ when compared with all other doses of potassium application which was at par with by $100 \mathrm{~kg}$ potassium hectare $\mathrm{ha}^{-1}$. Significantly minimum number of flower plant ${ }^{-1}$ (92.24), number of seed plant ${ }^{-1}(195.10)$, seed yield plant $^{-1}(26.50 \mathrm{~g})$, plot $^{-1}(547.06 \mathrm{~g})$ and hectare $^{-1}(9.12$ q) in control treatment. Potassium is a constituent of many energy rich compounds in the plants and also involved in active root growth and helps in uptake of other nutrient resulted in increased number of flower, number of seeds flower $^{-1}$ and seed yield of annual chrysanthemum. Similar findings were reported by Shinde et al., (2014), Kumar and Moon (2014), Singh and Kumar (2016) in African marigold.

Interaction effect of nitrogen and potassium

An interaction effect on nitrogen and potassium on all the vegetative and seed yield parameters were found to be non-significant. However, an application of $200 \mathrm{~kg}$ nitrogen and $75 \mathrm{~kg}$ potassium $\mathrm{ha}^{-1}$ was found to be better for obtaining maximum vegetative growth seed yield of annual chrysanthemum

\section{Acknowledgement}

The author is grateful to Horticulture Section, College of Agriculture, Nagpur-440001
(M.S.) India for providing the logistic support facilities to carry out this study

\section{References}

Chavan, M. D., Jahav P. B. and Rugge V. C., 2010. Performance of China aster varieties and their response to different levels of nitrogen. Indian J. Hort. 67: 378-381

Kabariel, J. Subramanian, S. and Kumar, M., 2016. Integrated nutrient management on growth and yield of African marigold (Tagetes erecta L) hybrid L 3 grown asan intercrop in Grand nain Banana. Int. J. Sci. and Nature. 7(2): 291-295.

Karavadia, B. N. and Dhaduk, B. K., 2000. Effect of spacing and nitrogen on annual chrysanthemum (Chrysanthemum coronarium) cv. Local White. J. Ornamental Horticulture, 5(1): 65-66.

Karetha, K. M., Jat, Giriraj, Singh, Virendra and. Gajipara, N. N, 2011. Effect of different levels of NPK on growth, yield and yield attributes of gaillardia (Gaillardia pulchella) cv. Local Double. The Asian J. Hort. 6(2): 344347.

Kumar, N. V. and Moon, S. S., 2014. Effect of phosphorus and potassium on seed quality and seed yield of African marigold. J. Soils and Crops. 24(2): 346-350

Kumar, P., Kumar, Vijay and Kumar, Deepak, 2016. Response of INM to plant growth, flower yield and shelf life of African marigold (Tagetes erecta L) cv. Pusa Basanti Gainda. Int. J. Agric. Invention. 1(1): $108-112$.

Mittal, R. H. Patel, C., Nayee, D. D and Sitapara, H. H., 2010. Effect of integrated nutrient management on growth and yield of African marigold (Tagetus erecta L) cv. 'Local' under 
middle Gujarat agro-climatic conditions. The Asian J. Hort. 5(2): 347-349.

Palagani, N. Barad, A. V. and Bhosale. Nilima, 2015. Response of chrysanthemum (Chrysanthemum morifolium Ramat) cv. IIHR-6 to integrated nutrient management. Bioinfonet. 12(1A): 79-84.

Panse, U.G. and Sukhane. B. V., 1967. Statistical methods for agriculture workers, ICAR publications, New Delhi. 100-161.

Shinde, Manisha, Khiratkar, S. D., Ganjure, Surekha and Bahadure, Rohit, 2014. Response of nitrogen and potassium levels on growth, flowering and seed yield of African marigold. J. Soils and Crops. 24(1): $89-94$.

Singh, J. and Nigam. Rashmi, 2015. Effect of PGRs and inorganic fertilizers on vegetative growth and flowering behavior of chrysanthemum, HortiFlora Res. Spectrum. 4(3): 273-276.
Singh, U. and Kumar, Vikas, 2016. Studies on efficiency of integrated nutrient management on growth and yield of marigold (Tagetes erecta L.) cv. Pusa Narangi Gainda. Adv. Life Sci. 5(20): 9252-9258.

Solanki, R. B. and Ganie, Nisar Ahmad, 2010. Growth and flowering of African marigold as affected by nitrogen and phosphorus under varying intra- row spacing. The Asian. J. Hort. 4(2): 418420

Teja, Ravi P., Bhaskar, V. Vijaya, Dorajeerao, A. V. D and Subbaramamma, P., 2017. Effect of graded levels of nitrogen and potassium on Growth and flower yield of annual chrysanthemum (Chrysanthemum coronarium L.). Plant Archives. 17(2):1371-1376.

Tembhare, V. J., Badge, S., Panchbhai, D. M and. Ragtate, S. R., 2016. Flowering, seed yield and quality of China aster as influenced by application of nitrogen and phosphorus. Plant Archives. 16(1): 356-360.

\section{How to cite this article:}

Nikam, B.S., S.A. Badge and Pawar, A.R. 2018. Growth and Seed Yield of Annual Chrysanthemum as Influenced by Different Levels of Nitrogen and Potassium. Int.J.Curr.Microbiol.App.Sci. 7(09): 563-568. doi: https://doi.org/10.20546/ijcmas.2018.709.067 